\author{
이서은 - 이준호* \\ 대구대학교 식품공학과
}

\title{
Quality and Antioxidant Properties of Sponge Cakes Incorporated with Pine Leaf Powder
}

\author{
Seo Eun Lee and Jun Ho Lee* \\ Department of Food Science and Engineering, Daegu University
}

\begin{abstract}
The effect of baking on the physicochemical and sensory properties was investigated using a model system of sponge cakes incorporated with pine leaf powder (PLP) as a value-added food ingredient. PLP was incorporated into cake batter at 5 levels $(0,2,4,6$, and $8 \%, \mathrm{w} / \mathrm{w})$ by adding an equivalent amount based on the weight of wheat flour. After appropriate mixing, sponge cakes were baked at $170^{\circ} \mathrm{C}$ for $30 \mathrm{~min}$ in an oven. The baked cakes were cooled to room temperature for $1 \mathrm{~h}$ prior to all measurements. The $\mathrm{pH}$, moisture content, specific volume, height, volume index, and symmetry index decreased significantly with the increase in PLP content $(p<0.05)$. On the contrary, specific gravity of the batter and baking loss increased $(p<0.05)$. The lightness of the cakes decreased, whereas redness increased significantly with the higher amount of PLP in the formulation $(p<0.05)$. Hardness also increased significantly $(p<0.05)$. Both total polyphenol content and DPPH (1,1-diphenyl-2-picryl hydrazyl) radical scavenging activity increased significantly by the addition of PLP $(p<0.05)$. The consumer acceptance test indicated that the addition of PLP up to $4 \%$ did not cause a significant unfavorable effect on the consumer acceptances in all attributes. The sponge cakes with 2-4\% PLP would be recommended with respect to the overall acceptance score while taking advantage of the functional properties of PLP without sacrificing the consumer acceptability.
\end{abstract}

Keywords: sponge cake, pine leaf powder, quality, antioxidant properties, consumer acceptance

\section{서 론}

소나무(Pinus densiflora Sieb. et Zucc.)는 소나무과에 속하는 침 엽상록수로 나무의 정기가 많고 사계절 내내 구하기 쉬우며 약 효가 월등하다고 알려져 있다(1). 한편 솔잎은 예로부터 차로 애 용되어 왔으며, 송편을 쪄서 먹을 때 솔잎의 향이 이용되기도 하 고(2), 최근에는 음식뿐만 아니라 비누, 치약 등으로 그 사용범위 가 넓어지고 있다.

솔잎의 주 생리활성 성분으로는 정유성분인 $\alpha$-pinene, $\beta$-pinene, camphene, borneol, phellandrene 등이 있고 플라보노이드류인 quercertin, kaempferol 등이 있다(3). 솔잎추출물은 식품의 부패와 식중독균의 생육억제에 효과가 있고 혈청 콜레스테롤을 저하시 킨다고 보고된 바 있다 $(4,5)$. 솔잎의 phenol 화합물은 노화와 발 암을 예방하고 신경쇠약증, 괴혈병, 탈모 등에 뛰어난 효과를 나 타내기도 한다 $(1,6)$. 그밖에 효능으로 간장 질환, 위장질환, 신경 계질환, 순환기계질환, 피부보호 등의 기능이 있으며 고혈압, 동 맥경화증, 중풍, 부종, 불면증, 습진, 신장병, 빈혈, 우울증, 뇌졸

*Corresponding author: Jun Ho Lee, Department of Food Science and Engineering, Daegu University, Gyeongsan, Gyeongbuk 712714 , Korea

Tel: 82-53-850-6535

Fax: 82-53-850-6539

E-mail: leejun@daegu.ac.kr

Received October 28, 2012; accepted November 27, 2012
중, 감기, 위장병 등을 예방하는 효과도 있다고 보고되고 있다(1).

한편 경제발전과 더불어 소득이 증대됨에 따라 개인의 건강과 건강식품에 대한 관심과 요구가 높아져 친환경유기농식품, 건강 식품, 기능성식품 등의 건강 지향적인 식생활에 대해 보다 많은 관심을 갖게 되었다(7). 최근에는 제과 및 제빵 분야에서 건강 지 향적인 제품의 개발이 점차 확대되고 있다. 현재까지 솔잎(또는 솔잎추출물)은 쿠키(2) 및 식빵(8)에 성공적으로 부재료로 사용된 바 있고, 이를 첨가한 국수(9) 및 반죽의 물리적 특성(10)에 관한 연구가 보고되었다.

따라서 본 연구에서는 건강 기능성식품들에 대한 관심이 증대 되고 있는 가운데 생리적 기능성이 우수한 솔잎 분말을 첨가한 스 펀지 케이크를 제조하고 물리·화학적, 항산화 활성 및 관능적 품 질특성을 조사함으로써 우수한 맛, 기능성, 그리고 기호성이 있는 스펀지 케이크를 개발하는데 필요한 기초자료를 제공하고자 하였다.

\section{재료 및 방법}

재료

본 연구에서 사용된 솔잎 분말(Jirisan Hanyaknara Co., Seoul, Korea)은 $70^{\circ} \mathrm{C}$ 에서 약 3 시간 열풍건조를 한 것으로 구입하여 사 용하였다. 시판용 1등급 박력밀가루(CJ Cheiljedang Co., Seoul, Korea), 설탕(CJ Cheiljedang Co., Seoul, Korea), 무가염 버터 (Seoul Dairy Co., Seoul, Korea), 소금 및 계란 등은 시중에서 구 입하여 사용하였다. 
Table 1. Formulations of sponge cakes prepared with pine leaf powder

\begin{tabular}{lccccc}
\hline \multirow{2}{*}{ Ingredients $(\mathrm{g})$} & \multicolumn{5}{c}{ Pine leaf powder level (\%) } \\
\cline { 2 - 6 } & 0 & 2 & 4 & 6 & 8 \\
\hline Wheat flour & 250 & 250 & 250 & 250 & 250 \\
Pine leaf powder & 0 & 5 & 10 & 15 & 20 \\
Whole egg & 450 & 450 & 450 & 450 & 450 \\
Sugar & 300 & 300 & 300 & 300 & 300 \\
Salt & 2.5 & 2.5 & 2.5 & 2.5 & 2.5 \\
Butter & 50 & 50 & 50 & 50 & 50 \\
\hline
\end{tabular}

\section{스펀지 케이크의 제조}

솔잎 분말을 첨가한 스펀지 케이크의 배합비는 Table 1 과 같 다. 솔잎 분말은 박력분 중량을 기준으로 $0-8 \%$ 를 첨가하였다. 먼 저 mixing bowl에 계란을 4 배속으로 1 분간 풀고 설탕, 소금을 혼 합한 후 믹서(5K5SS, KitchenAid Inc., St. Joseph, MI, USA)를 이용하여 6 배속으로 8 분간 거품을 형성시켰다. 그리고 체에 친 밀가루와 솔잎 분말을 첨가해 2-3분간 혼합시킨 후 중탕시킨 버 터를 첨가하여 3-4분간 혼합한 후 $500 \mathrm{~g}$ 씩 파운드 팬에 부었다. 파운드 팬을 $170^{\circ} \mathrm{C}$ 로 예열된 오븐 $(\mathrm{KXS}-4 \mathrm{G}+\mathrm{H}$, Salva Industrial S.A., Lezo, Spain)에서 30분간 구웠다. 완성된 스펀지 케이크는 실온에서 1 시간 방냉한 후 실험에 사용하였다.

\section{$\mathrm{pH}$ 와 반죽의 비중}

$\mathrm{pH}$ 는 케이크의 내부(crumb) $10 \mathrm{~g}$ 을 $90 \mathrm{~mL}$ 증류수와 혼합한 후 균질기로 1 분간 균질화 시킨 후 $\mathrm{pH} \operatorname{meter}(\mathrm{pH} / \mathrm{Ion} 510$, Oakton Instruments, Vernon Hills, IL, USA)을 이용하여 5회 반복 측정하 여 평균값을 구하였다. 반죽의 비중(specific gravity)은 American Association of Cereal Chemists(AACC) method 10-15(11)에 따라 반죽이 완성된 후 물에 대한 반죽 무게의 비로 나타내었다.

\section{수분함량과 굽기손실}

수분함량은 케이크의 껍질(crust)을 제거한 후 약 $5 \mathrm{~g}$ 씩 시료를 취하여 $105^{\circ} \mathrm{C}$ 상압건조법을 이용하여 5 회 반복 측정하였다. 굽 기손실(baking loss)은 반죽무게와 케이크무게를 측정하여 아래의 식으로 계산하였다.

$$
\text { Baking loss }(\%)=\frac{\mathrm{W}_{\text {batter }}-\mathrm{W}_{\text {cake }}}{\mathrm{W}_{\text {batter }}} \times 100
$$

\section{비체적 및 높이}

케이크의 비체적 $(\mathrm{mL} / \mathrm{g})$ 은 케이크를 1 시간 방냉한 후 종자치환 법(12)으로 부피를 측정하고 시료의 무게로 나누어 계산하였다. 케이크의 높이는 케이크의 정중앙 부분을 단면으로 잘라 template 를 이용하여 5 회 반복 측정하였다.

\section{부피지수 및 대칭성지수}

케이크의 부피지수(volume index) 및 대칭성지수(symmetry index)는 케이크의 정중앙 부분을 단면으로 자른 후에 AACC method 10-91(13)에 따라 5회 반복하여 측정하였다.

\section{색도 및 외관촬영}

케이크를 1시간 방냉한 후 crumb의 색도를 색차계(Spectrophotometer, CM-600d, Minolta Co., Osaka, Japan)를 사용하여 측정하
였다. 케이크의 $L^{*}$ (명도), $a^{*}$ (적색도), $b^{*}$ (황색도)값을 측정하여 5 회 반복 측정하여 평균값을 구하였다. 외관촬영은 디지털 사진기 (VLUU ST600, Samsung, Seoul, Korea)를 사용하였으며, 같은 시 간, 장소, 조명에서 시료와 사진기의 거리를 동일하게 하여 외관 의 색도를 비교하였다.

\section{경도}

경도(Hardness)는 Advanced Universal Testing System(LRXPlus, Lloyd Instrument Ltd., Fareham, Hampshire, UK)을 이용하여 실 온에서 15 회 반복 측정한 후 평균값을 비교하였다. 케이크는 1 시 간 방냉한 후 사용하였으며, 시료의 크기는 $3 \times 3 \times 3 \mathrm{~cm}$, test speed 는 $2.0 \mathrm{~mm} / \mathrm{s}$, trigger 조건은 $20 \mathrm{~g}_{\mathrm{f}}$ 이었으며, 지름과 높이가 각각 $12.45,50.00 \mathrm{~mm}$ 인 원기둥형 탐침(probe)을 사용하였다.

\section{총 페놀화합물 함량}

총 폴리페놀 함량은 Folin-Ciocalteu 방법을 응용하여 측정하였 다. 내부(crumb)의 시료 $5 \mathrm{~g}$ 을 $70 \%$ ethanol(Merk KGaA, Darmstadt, Germany) $50 \mathrm{~mL}$ 와 혼합하고 1시간동안 추출시킨 후 8,000 $\mathrm{rpm}$ 에서 10 분간 원심분리하고 Whatman No. 1 여과지로 10 분 동 안 여과하여 시료로 사용하였다. 시료용액은 10 배 희석하여 $1 \mathrm{~mL}$ 를 넣고, $2 \mathrm{~N}$ Folin-Ciocalteu reagent(Sigma Aldrich Corp., St. Louis, MO, USA) $1 \mathrm{~mL}, \quad 35 \% \quad \mathrm{Na}_{2} \mathrm{CO}_{3}$ (Crown Guaranteed Reagents, Kyoto, Japan) $2 \mathrm{~mL}$, 증류수 $2 \mathrm{~mL}$ 를 가하여 혼합하고 실온에서 30 분 동안 방치시킨 다음 분광광도계(Optizen $2020 \mathrm{UV}$ Plus, Mecasys Ltd., Daejeon, Korea)를 사용하여 $700 \mathrm{~nm}$ 에서 흡광 도를 측정하였다. 표준물질로서 gallic acid를 사용하여 검량선을 작성하였다.

\section{$\mathrm{DPPH}$ (1,1-diphenyl-2-picrylhydrazyl) 전자공여능}

$70 \%$ ethanol $50 \mathrm{~mL}$ 에 DPPH(Wako, Kyoto, Japan) 시약 0.006 $\mathrm{g}$ 을 햇빛을 차단하여 1 시간 용해시킨 후 Whatman No. 1 여과지 로 여과하였다. 여과한 용액에 $100 \mathrm{~mL}$ 의 증류수를 가한 후 흡광 도를 측정하여 1.0 으로 맞추었다. 시료 $2.5 \mathrm{~g}$ 과 $70 \%$ ethanol 50 $\mathrm{mL}$ 를 혼합하여 1 시간 동안 추출 시킨 후 $8,000 \mathrm{rpm}$ 에서 10 분간 원심분리하고 Whatman No. 1 여과지로 10 분 동안 여과하여 시 료로 사용하였다. 시료 $1 \mathrm{~mL}$ 와 DPPH용액 $5 \mathrm{~mL}$ 를 10 분 동안 상 온에서 방치한 후 $517 \mathrm{~nm}$ 에서 흡광도를 측정하였다. 대조구는 5 $\mathrm{mL} \mathrm{DPPH}$ 용액 대신에 $5 \mathrm{~mL} 70 \%$ ethanol 용액을 사용하였다.

\section{소비자 기호도 검사}

소비자 기호도 검사는 무작위로 선발된 대학생 50 명(남자 22 명 여자 28명, 20-27세)을 대상으로 실시하였다. 각 시료를 $2.5 \times$ $2.5 \times 2.5 \mathrm{~cm}$ 크기로 잘라 세자리 난수표로 구분하여 종이접시 위 에 나열한 후 제시되었으며, 9점 척도(1: 대단히 싫어함, 9: 대단 히 좋아함)를 사용하여 평가하였다. 평가항목은 색(color), 향미 (flavor), 맛(taste) 및 전체적 기호도(overall acceptance)였으며, 시 료 간 잔향 및 잔미의 방해를 최소화하기 위하여 새 시료를 평 가할 때마다 물을 이용하여 입안을 충분히 헹군 후 검사를 실시 하도록 하였다.

\section{통계 처리}

실험결과는 SAS 9.1(SAS Institute Inc., Cary, NC, USA)(14)를 이용하여 분산분석을 실시하였고, 유의성 검증은 Duncan's multiple range test에 의해 분석하였다 $(p<0.05)$. 


\section{결과 및 고찰}

\section{$\mathrm{pH}$ 와 반죽의 비중}

솔잎 분말을 첨가하여 제조한 스펀지 케이크의 $\mathrm{pH}$ 와 비중은 Table 2에 요약된 바와 같다. 솔잎 분말 $(\mathrm{pH} 4.6)$ 의 첨가량이 증가 할수록 케이크의 $\mathrm{pH}$ 는 유의적으로 감소하는 경향이 보였다 $(p<0.05)$. 부재료의 첨가량이 증가함에 따라 케이크의 $\mathrm{pH}$ 가 감소하는 현상 은 야콘 분말(15), 흑마늘 분말(16), 청경채(17)를 이용한 스펀지 케이크에서도 보고된 바 있는데 부재료로 첨가되는 시료의 $\mathrm{pH}$ 가 상대적으로 낮기 때문으로 판단된다. 한편 스펀지 케이크의 일반 적인 $\mathrm{pH}$ 값의 범위는 7.3-7.6으로 보고된 바 있는데(16), 본 실험 에서 얻어진 스펀지 케이크의 경우 이보다 다소 높게 나타났는 데 이는 각 연구에서 사용한 시료의 다양성에 기인하는 것으로 판단된다. 일반적인 $\mathrm{pH}$ 범위에서 벗어나 알칼리성 쪽에 가까워지 면 기공이 거칠고 껍질색과 속색이 어두워지는 특징이 있다(18). 반죽의 비중은 스펀지 케이크의 부피와 조직감에 영향을 미치 게 되는데, 비중이 높을수록 반죽의 기포 함유량이 적어져 구운 후의 부피가 감소하게 되고 솔잎 분말 첨가량이 증가할수록 솔 잎이 밀가루보다 무기질, 섬유소 비율이 높아서 조직이 거칠어진 다 $(19,20)$. 본 실험에서는 대조군과 $2 \%$ 첨가군은 유의적인 차이없 이 증가하였고, 솔잎 분말 첨가량이 증가할수록 비중이 증가하는 경향을 나타내었다. 야콘 분말(15), 청경채(17), 감태 분말(21), 마 (22)를 첨가한 스펀지 케이크에서도 유사한 경향이 나타났다. 이 는 솔잎 분말이 반죽과정에서 교반 시 형성된 계란 거품의 유화 를 방해해서 기포가 파괴되어 비중의 증가하게 되는 것으로 사 료된다(23).

\section{수분함량과 굽기손실}

솔잎 분말의 첨가량에 따라 제조한 스펀지 케이크의 수분함량 과 굽기손실은 Table 2에 나타나 있다. 솔잎 분말 첨가량이 증가 할수록 수분함량은 유의적으로 감소하였는데 $(p<0.05)$, 이러한 감 소 현상은 야콘 분말(15), 흑마늘 분말(16), 바나나 분말(24), 등 을 첨가한 스펀지 케이크에서도 나타났다. 이는 솔잎 분말을 첨 가한 스펀지 케이크의 경우 솔잎 분말의 식이섬유소에 의한 수 분흡착 작용으로 첨가군이 대조군보다 수분함량이 낮은 것으로 판단된다(25).
굽기과정 중에 반죽이 열에 의해 부풀어지고 반죽 내 기공에 서 수분이 기화됨에 따라 굽기손실이 나타난다(26). 대조군의 굽 기손실은 12.08 로 가장 낮았고 솔잎 분말을 첨가할수록 굽기손실 은 유의적으로 증가하는 경향을 나타내었다 $(p<0.05)$. 한편 굽기 손실은 수분함량과 양의 상관관계에 있고, 굽기손실의 증가현상 은 야콘 분말(15), 감태 분말(21), 매생이 분말(26)을 첨가한 스펀 지 케이크에서도 확인할 수 있다.

\section{비체적 및 높이}

솔잎 분말의 첨가량에 따라 제조한 스펀지 케이크의 비체적과 높이는 Table 3에 나타내었다. 케이크의 비체적은 솔잎 분말의 첨 가량이 증가할수록 점차적으로 감소하는 경향을 나타내었고, 대 조군과 $2,4 \%$ 첨가군 사이에 유의적인 차이는 나타내지 않았지만 이 후 $6,8 \%$ 첨가군에서 유의적으로 감소하였다 $(p<0.05)$. 이는 솔 잎 분말의 첨가로 인한 글루텐의 희석작용에 의해 글루텐의 결 합력이 약화되어 공기 포집력이 감소했기 때문이라고 판단되며 (16), 이와 같은 비체적의 감소현상은 감태 분말(21), 흑미가루(24), 마(22), 꾸지뽕잎 분말(27)을 첨가한 스펀지 케이크에서도 보고된 바 있다. 한편 케이크의 높이는 솔잎 분말의 첨가량이 증가할수 록 유의적으로 감소하는 경향을 나타내었다 $(p<0.05)$. 솔잎 분말 에는 식이섬유가 풍부하여 스편지 케이크 제조시 반죽의 가스 보 유력이 감소하기 때문에 부피가 감소하는 경향을 나타내는 것으 로 판단된다(29).

\section{부피지수 및 대칭지수}

케이크의 겉모양을 나타내는 부피지수(volume index) 및 대칭 지수(symmetry index)는 Table 3에 나타내었다. 부피지수는 대조 군이 $169.46 \mathrm{~mm}$ 로 가장 높은 값을 나타냈고, 솔잎 분말의 첨가 량이 증가할수록 부피지수는 점점 감소하여 $8 \%$ 첨가군은 가장 낮은 값인 $142.41 \mathrm{~mm}$ 로 부피가 감소한 것을 알 수 있다. 이러한 결과는 앞서 설명한 반죽의 비중과 밀접한 관계가 있으며, 바나 나분말(24), 흑미가루(28), 조 분말(30), 홍삼박 분말(31)을 이용해 제조한 스펀지 케이크 등에서도 유사한 감소현상이 보고되었다.

한편 대칭지수는 케이크의 정중앙부분과 양쪽의 측면부분의 높 이 차이를 나타낸 것이로(32), 대칭지수가 높다는 것은 정중앙부 분이 높게 구워진 것을 의미하는데 본 실험에서는 솔잎 분말 첨

Table 2. pH, specific gravity, moisture content, and baking loss of cake (or batter) as affected by pine leaf powder

\begin{tabular}{|c|c|c|c|c|c|}
\hline \multirow{2}{*}{ Properties } & \multicolumn{5}{|c|}{ Pine leaf powder level (\%) } \\
\hline & 0 & 2 & 4 & 6 & 8 \\
\hline pH (cake) & $8.68 \pm 0.01^{\mathrm{a}}$ & $8.40 \pm 0.01^{b}$ & $8.14 \pm 0.02^{c}$ & $7.84 \pm 0.01^{\mathrm{d}}$ & $7.75 \pm 0.02^{\mathrm{e}}$ \\
\hline Specific gravity (batter) & $0.41 \pm 0.01^{\mathrm{c}}$ & $0.46 \pm 0.07^{\mathrm{c}}$ & $0.58 \pm 0.02^{b}$ & $0.74 \pm 0.03^{\mathrm{a}}$ & $0.79 \pm 0.02^{\mathrm{a}}$ \\
\hline Moisture content (\%) & $35.67 \pm 0.61^{\mathrm{a}}$ & $34.96 \pm 0.40^{\mathrm{a}}$ & $34.50 \pm 1.81^{\mathrm{ab}}$ & $32.10 \pm 2.18^{\mathrm{bc}}$ & $31.71 \pm 3.72^{c}$ \\
\hline Baking loss $(\%)$ & $12.08 \pm 0.26^{\mathrm{d}}$ & $12.99 \pm 0.04^{\mathrm{d}}$ & $15.74 \pm 0.05^{\mathrm{c}}$ & $17.04 \pm 0.06^{\mathrm{b}}$ & $17.11 \pm 0.01^{\mathrm{a}}$ \\
\hline
\end{tabular}

${ }^{a-e}$ Means within the same row without a common letter are significantly different $(p<0.05)$.

Table 3. Specific volume, height, volume index, and symmetry index of sponge cakes as affected by pine leaf powder

\begin{tabular}{lrrrrr}
\hline \multirow{2}{*}{ Properties } & \multicolumn{5}{c}{ Pine leaf powder level (\%) } \\
\cline { 2 - 6 } & \multicolumn{1}{c}{0} & \multicolumn{1}{c}{4} & \multicolumn{1}{c}{6} & \multicolumn{1}{c}{. } \\
\hline Specific volume $(\mathrm{mL} / \mathrm{g})$ & $3.16 \pm 0.07^{\mathrm{a}}$ & $3.16 \pm 0.11^{\mathrm{a}}$ & $3.10 \pm 0.02^{\mathrm{a}}$ & $2.85 \pm 0.03^{\mathrm{b}}$ & $2.53 \pm 0.00^{\mathrm{c}}$ \\
Height (mm) & $64.53 \pm 0.31^{\mathrm{a}}$ & $63.75 \pm 0.46^{\mathrm{b}}$ & $61.94 \pm 0.59^{\mathrm{c}}$ & $59.16 \pm 0.54^{\mathrm{d}}$ & $53.60 \pm 0.50^{\mathrm{e}}$ \\
Volume index & $169.46 \pm 0.90^{\mathrm{a}}$ & $168.66 \pm 0.36^{\mathrm{a}}$ & $166.60 \pm 0.77^{\mathrm{b}}$ & $156.54 \pm 0.63^{\mathrm{c}}$ & $142.41 \pm 0.87^{\mathrm{d}}$ \\
Symmetry index & $23.16 \pm 1.72^{\mathrm{a}}$ & $21.45 \pm 0.61^{\mathrm{b}}$ & $20.29 \pm 0.77^{\mathrm{bc}}$ & $19.17 \pm 0.53^{\mathrm{c}}$ & $14.91 \pm 0.16^{\mathrm{d}}$ \\
\hline
\end{tabular}

\footnotetext{
${ }^{a-e}$ Means within the same row without a common letter are significantly different $(p<0.05)$.
} 
Table 4. Color characteristics of sponge cakes as affected by pine leaf powder

\begin{tabular}{crrrrr}
\hline \multirow{2}{*}{ Properties } & \multicolumn{5}{c}{ Pine needle leaf level (\%) } \\
\cline { 2 - 6 } & \multicolumn{1}{c}{0} & \multicolumn{1}{c}{4} & \multicolumn{1}{c}{6} & \multicolumn{1}{c}{. } \\
\hline$L^{*}$ & $81.12 \pm 0.74^{\mathrm{a}}$ & $65.05 \pm 0.40^{\mathrm{b}}$ & $61.38 \pm 0.45^{\mathrm{c}}$ & $56.38 \pm 0.68^{\mathrm{d}}$ & $54.33 \pm 0.58^{\mathrm{e}}$ \\
$a^{*}$ & $1.01 \pm 0.22^{\mathrm{a}}$ & $2.64 \pm 0.10^{\mathrm{b}}$ & $3.62 \pm 0.11^{\mathrm{c}}$ & $4.05 \pm 0.11^{\mathrm{d}}$ & $4.39 \pm 0.14^{\mathrm{e}}$ \\
$b^{*}$ & $35.56 \pm 0.46^{\mathrm{a}}$ & $26.35 \pm 0.21^{\mathrm{c}}$ & $26.44 \pm 0.33^{\mathrm{bc}}$ & $26.52 \pm 0.50^{\mathrm{bc}}$ & $26.93 \pm 0.33^{\mathrm{b}}$ \\
\hline
\end{tabular}

${ }^{\mathrm{a}-\mathrm{e}}$ Means within the same row without a common letter are significantly different $(p<0.05)$.

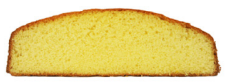

0

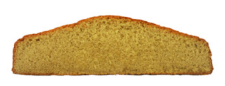

2

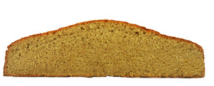

4

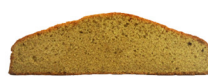

6

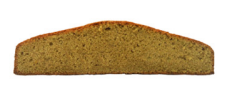

8

Pine leaf powder $(\%)$

Fig. 1. Visual comparison of sponge cakes incorporated with different levels of pine leaf powder.

가량이 증가할수록 대칭지수는 유의적으로 감소되는 경향을 나 타내었다 $(p<0.05)$. 이는 솔잎 분말 첨가량이 증가할수록 케이크 의 중앙부분이 평평하게 형성되는 것을 의미하며, 최종 굽기과정 에서 시료내의 가스보존이 중요한 영향을 미치는 것으로 알려져 있다(32). 마(22), 뽕잎 분말(33), 감잎 분말(34)을 첨가한 스편지 케이크의 경우 본 연구결과와 유사한 대칭지수 감소를 보고하였다.

\section{색도 및 외관촬영}

솔잎 분말을 첨가하여 만든 스펀지 케이크의 색도는 Table 4, 외관의 색과 모양을 비교한 사진은 Fig. 1 에 나타내었다. 케이크 의 $\operatorname{crumb}$ (내부)의 색도에서 명암을 나타내는 $L^{*}$ 값은 솔잎 분말 첨가량이 증가할수록 81.12-4.33으로 단계별로 유의적인 감소를 보였다 $(p<0.05)$. 새송이 버섯 분말(35), 김 분말(36), 파프리카(37), 부추(38)를 첨가한 스펀지 케이크에서도 유사한 결과가 보고된 바 있다. 적색도를 나타내는 $a^{*}$ 값은 솔잎 분말 첨가량이 증가할 수록 단계별로 유의적으로 증가하는 경향을 나타내었고 $(p<0.05)$, 황색도를 나타내는 $b^{*}$ 값은 대조군에서 최대값을 나타내고 $2 \%$ 첨 가군이 최소값을 나타낸 후 솔잎 첨가량이 증가할수록 미미하게 증가하는 경향을 나타내었다. 한편 솔잎 분말의 $L^{*}, a^{*}, b^{*}$ 값은 각각 $61.20,0.58,19.90$ 으로 나타나 이 중 특히 낮은 $L^{*}$ 값이 스 펀지 케이크의 전반적인 색도에 직접적인 영향을 미치는 것으로 판단된다.

\section{경도}

솔잎 분말을 첨가하여 제조한 스펀지 케이크의 경도(Hardness) 를 측정한 결과는 Fig. 2와 같다. 스펀지 케이크의 경도는 대조 군, $2 \%$ 첨가군, $4 \%$ 첨가군이 유의적인 차이없이 낮았고 $(p>0.05)$, $8 \%$ 첨가군이 타 시료에 비해 유의적으로 가장 높은 값을 나타 내었다 $(p<0.05)$. 이와 같은 결과는 케이크 제조 시 솔잎 분말에 의하여 기포형성과 케이크 팽창이 억제되고, 따라서 기공이 발달 되지 않아 부피는 줄어들고 경도가 증가된 것으로 판단된다(39). 청경채(17), 감태 분말(21), 마(22), 바나나 분말(24) 등을 첨가한 스펀지 케이크에서도 유사한 결과가 나타났다.

\section{총 페놀화합물 함량}

솔잎 분말을 첨가하여 만든 스펀지 케이크의 총 페놀화합물 함 량은 Fig. 3과 같다. 대조군의 총 페놀화합물 함량은 $21.77 \mathrm{GAE}$ $\mathrm{mg} / \mathrm{g}$ 이고 $2,4,6,8 \%$ 첨가군에서 각각 $22.82,23.28,23.53$, $23.83 \mathrm{GAE} \mathrm{mg} / \mathrm{g}$ 값을 나타내었다. $4-6 \%$ 첨가군 사이에 유의적인

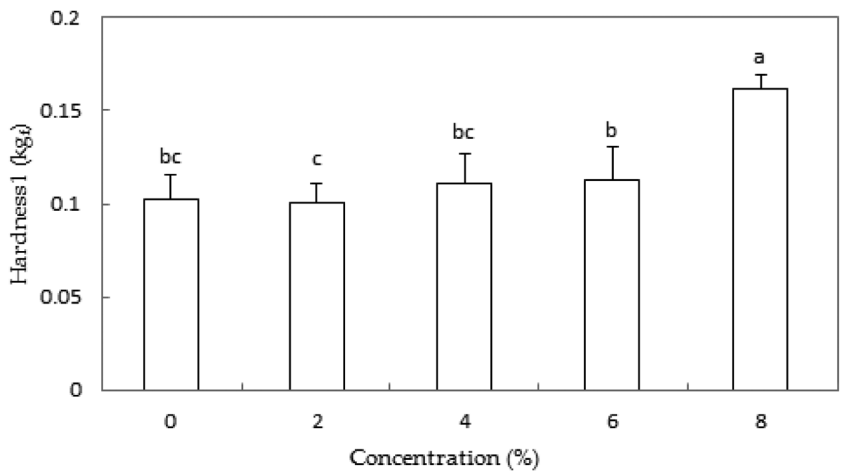

Fig. 2. Hardness of sponge cakes as affected by pine needle powder. Means without a common letter are significantly different $(p<0.05)$.

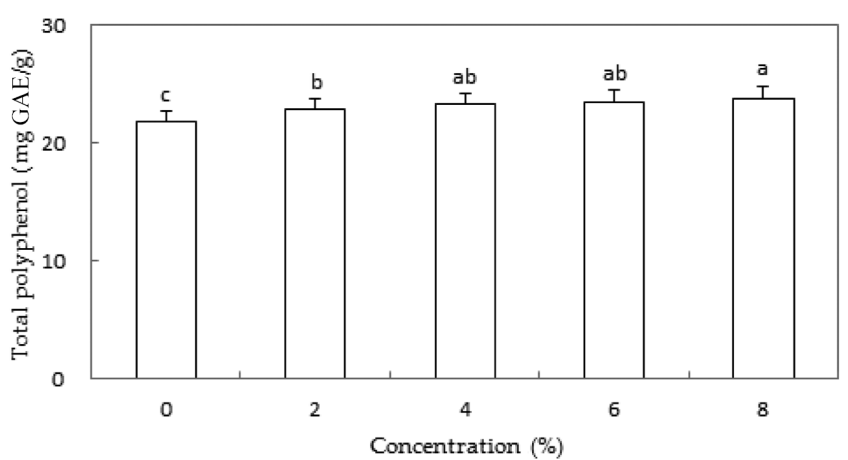

Fig. 3. Total polyphenol content of sponge cakes as affected by pine needle powder. Means without a common letter are significantly different $(p<0.05)$.

차이는 나타나지 않았지만 $(p>0.05)$, 전반적으로 다소 증가하는 경 향을 나타내었다. 식품에 많이 함유된 화학물질인 phytochemical 는 발암물질 생성을 억제하는 페놀화합물을 함유하고 있고 솔잎 분말을 첨가함으로써 총 페놀화합물의 함량이 증가하는 경향을 나타낸 것으로 사료된다(40). 야콘 분말(15), 꾸지뽕잎 분말(27)을 첨가한 스펀지 케이크에서도 유사한 결과가 보고되었다.

\section{$\mathrm{DPPH}$ 전자공여능}

솔잎 분말을 첨가하여 제조한 스펀지 케이크의 $\mathrm{DPPH}$ 전자공 


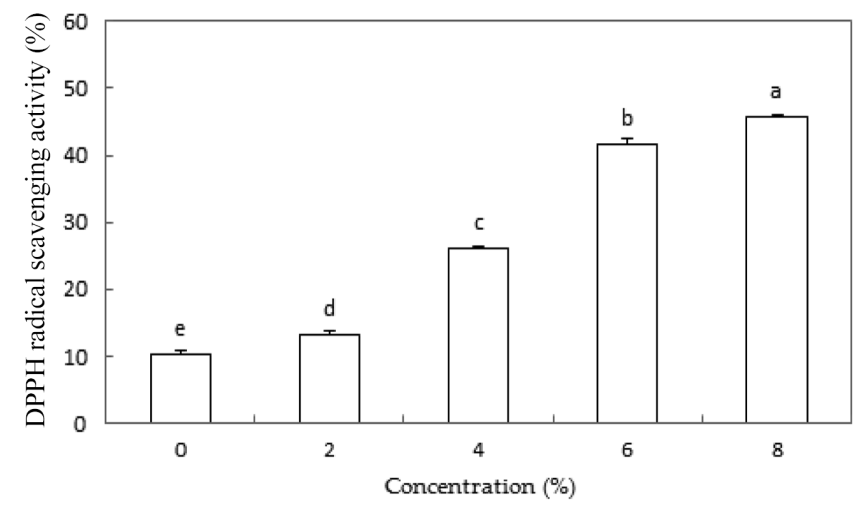

Fig. 4. Effects of DPPH radical-scavenging activity of sponge cakes as affected by pine needle powder. Means without a common letter are significantly different $(p<0.05)$.

여능은 Fig. 4에 나타내었다. 대조군의 DPPH는 $10.38 \%$ 이고 솔잎 분말 첨가량이 증가할수록 $13.33-45.76 \%$ 값이 나타나 단계별로 유의적으로 증가하는 경향이 나타났다 $(p<0.05)$. 이러한 결과는 솔 잎의 항산화작용으로부터 유래한 것으로 보여지며(41), 스펀지 케 이크의 제조시 솔잎 분말의 첨가는 일반 편이식품에 일부 항산 화효과를 손쉽게 부여할 수 있을 것으로 기대된다.

\section{소비자 기호도 검사}

솔잎 분말을 첨가한 스펀지 케이크의 색(color), 향미(flavor), 맛 (taste), 부드러움 정도(softness)와 전반적인 기호도(overall acceptance)에 대한 소비자 평가결과는 Table 5에 나타내었다. 스펀지 케이크의 색에 대한 선호도는 대조군이 가장 높게 나타났고, 첨 가량이 증가함에 따라 유의적으로 감소하는 경향을 나타내었다 $(p<0.05)$. 향미의 경우 대조군, $2 \%$ 및 $4 \%$ 첨가군 사이에 유의적 인 차이는 없었지만, $4 \%$ 첨가군, $2 \%$ 첨가군, 대조군의 순으로 높은 선호도를 나타냈다. 이는 스펀지 케이크에 넣은 솔잎의 향 이 계란의 비린 향을 없애주어 향미관점에서 미미하지만 소비자 들이 긍정적으로 평가한 것으로 판단된다. 하지만 $6 \%$ 첨가군, $8 \%$ 첨가군은 강한 솔잎 향으로 인해 오히려 낮은 선호도로 평 가되었다. 맛의 경우 대조군, $2 \%$ 첨가군, $4 \%$ 첨가군 사이에는 유의적인 차이는 없었고, $6 \%$ 첨가군, $8 \%$ 첨가군보다는 더 높은 기호도를 나타내었다.

전체적인 기호도 평가에서 대조군, $2 \%$ 첨가군, $4 \%$ 첨가군 사 이에 유의적인 차이는 없었으며, $6 \%$ 첨가군, $8 \%$ 첨가군은 유의 적으로 낮게 평가되었다. 따라서 모든 소비자 평가 항목에서 솔 잎 분말의 첨가농도가 $6 \%$ 를 초과하게 되면 소비자들이 솔잎의 진한 향과 맛으로 인해 다소 거부감을 표출하는 것으로 판단된 다. 그럼에도 색을 제외한 모든 항목에서 $2-4 \%$ 첨가군 사이에는
유의적 차이가 없는 것으로 평가되었으며, 따라서 솔잎 분말의 기능적 효능을 최대한 활용하면서 소비자들의 기호도를 만족시 킬 수 있는 최적 첨가농도는 $2-4 \%$ 가 가장 적절한 것으로 판단된다.

\section{요 약}

솔잎 분말의 첨가농도를 $0-8 \%$ 로 달리하여 스펀지 케이크를 제 조하고 물리화학적 품질, 항산화특성 및 소비자 기호도를 비교하 였다. 솔잎 분말의 첨가량이 증가할수록 케이크의 $\mathrm{pH}$ 는 단계별 로 유의적으로 감소하였고, 반죽의 비중은 유의적으로 증가하였 다 $(p<0.05)$. 한편 수분함량은 솔잎 분말 첨가에 따라 유의적으로 감소하였고 굽기손실은 증가하였다 $(p<0.05)$. 케이크의 비체적, 높 이, 부피지수 및 대칭지수 또한 유의적으로 감소하였다 $(p<0.05)$. 밝기를 나타내는 $L^{*}$ 값은 솔잎 분말 첨가량이 증가할수록 단계별 로 유의적으로 감소하였으며, 적색도를 나타내는 $a^{*}$ 값은 뚜렷한 증가를 나타내었다. 황색도를 나타내는 $b^{*}$ 값은 솔잎 분말 첨가에 따라 급격히 감소하였으나 농도의 영향은 미미한 것으로 나타났 다. 한편 케이크의 경도는 유의적으로 증가하였다 $(p<0.05)$. 항산 화특성을 나타내는 총 페놀화합물 함량과 $\mathrm{DPPH}$ 전자공여능은 솔잎 분말 농도에 따라 증가하는 경향을 나타내었으며 그 증가 효과는 $\mathrm{DPPH}$ 전자공여능에서 뚜렷하게 나타났다. 소비자 기호 도 검사 결과 대부분의 평가항목에서 대조군과 $2 \%, 4 \%$ 첨가군 사이에 유의적인 차이가 없었으며, 따라서 스펀지 케이크의 관능 적 품질과 건강 기능성 효과 등을 고려할 때 솔잎 분말을 $2-4 \%$ 첨가한 스펀지 케이크가 가장 적절한 것으로 판단된다.

\section{문 헌}

1. Kim WJ, Choi HS. Dry Spice. Hyoilbooks, Seoul, Korea. pp. 161-167 (2001)

2. Choi HY. Antioxidant activity and quality characteristics of pine needle cookies. J. Korean Soc. Food Sci. Nutr. 38: 1414-1421 (2009)

3. Kim YS, Shin DH. Volatile components and antibacterial effect of pine needle (Pinus densiflora S. and Z.) extracts. Food Microbiol. 22: 37-45 (2005)

4. Choi MY, Choi EJ, Lee E, Im TJ, Cha BC, Park HJ. Antimicrobial activities of pine needle (Pinus densiflora Seib. et Zucc.) extract. Korean J. Appl. Microbiol. Biotechnol. 25: 293-297 (1997)

5. Lee YH, Shin YM, Cha SH, Choi YS, Lee SY. Development of the health foods containing the extract from Pinus strobus leave. J. Korean Soc. Food Nutr. 25: 379-383 (1996)

6. Moon JJ, Han YB, Kim JS. Studies on antitumor effects of pine needles, Pinus densiflora Sieb. et Zucc. Korean Vet. Res. 33: 701-710 (1993)

7. Han JS, Kim JA, Han GP, Kim DS. Quality characteristic of functional cookies with added potato peel. Korean J. Food Cookery Sci. 20: 63-69 (2004)

8. Choi DM, Lee DS, Chung SK. Effect of fermentation pine needle

Table 5. Consumer acceptance of sponge cakes as affected by pine leaf powder

\begin{tabular}{lccccc}
\hline \multirow{2}{*}{ Attributes } & \multicolumn{5}{c}{ Pine leaf powder level (\%) } \\
\cline { 2 - 6 } & 0 & 2 & 4 & 6 & 8 \\
\hline Color & $7.48 \pm 1.54^{\mathrm{a}}$ & $6.36 \pm 1.56^{\mathrm{b}}$ & $6.26 \pm 1.38^{\mathrm{b}}$ & $5.58 \pm 1.66^{\mathrm{c}}$ & $5.40 \pm 1.73^{\mathrm{c}}$ \\
Flavor & $6.24 \pm 1.81^{\mathrm{a}}$ & $6.40 \pm 1.84^{\mathrm{a}}$ & $6.48 \pm 1.58^{\mathrm{a}}$ & $5.88 \pm 1.54^{\mathrm{ab}}$ & $5.62 \pm 2.02^{\mathrm{b}}$ \\
Taste & $6.52 \pm 1.52^{\mathrm{a}}$ & $6.30 \pm 1.65^{\mathrm{a}}$ & $6.16 \pm 1.94^{\mathrm{a}}$ & $5.28 \pm 1.72^{\mathrm{b}}$ & $5.12 \pm 2.09^{\mathrm{b}}$ \\
Overall acceptance & $6.42 \pm 1.51^{\mathrm{a}}$ & $6.34 \pm 1.59^{\mathrm{a}}$ & $6.22 \pm 1.56^{\mathrm{a}}$ & $5.14 \pm 1.73^{\mathrm{b}}$ & $4.94 \pm 1.93^{\mathrm{b}}$ \\
\hline
\end{tabular}

${ }^{\mathrm{a}-\mathrm{c}}$ Means within the same row without a common letter are significantly different $(p<0.05)$. 
extract on the quality of plain bread. Korean J. Food Preserv. 14: 154-159 (2007)

9. Jeong RJ, Kim HH, Park GS. Quality characteristics of noodles prepared with pine needle powder and extract during storage. Korean J. Food Cookery Sci. 21: 685-692 (2005)

10. Shin GM, Im JC. Rheological properties of dough added with pine needle powder. Korean J. Food Preserv. 15: 405-410 (2008)

11. AACC. Approved Methods of the AACC. Method 10-15. American Association of Cereal Chemists, St. Paul, MN, USA (2000)

12. AACC. Approved Methods of the AACC. Method 74-09. American Association of Cereal Chemists, St. Paul, MN, USA (1988)

13. AACC. Approved Methods of the AACC. Method 10-91. American Association of Cereal Chemists, St. Paul, MN, USA (2000)

14. SAS. SAS User's Guide. Ver. 9.1, SAS Institute, Cary, NC, USA (2005)

15. Lee JH, Son SM. Quality of sponge cakes incorporated with yacon powder. Food Eng. Prog. 15: 269-275 (2011)

16. Lee JS, Seong YB, Jeong BY, Yoon SJ, Lee IS, Jeong YH. Quality characteristics of sponge cake with black garlic powder added. J. Korean Soc. Food Sci. Nutr. 38: 1222-1228 (2009)

17. Chung YS, Kim DJ. Quality characteristics of sponge cake with pakchoi. J. Korean Soc. Food Sci. Nutr. 38: 914-919 (2009)

18. Ash DJ, Colmey JC. The role of $\mathrm{pH}$ in cake baking. Bakers Dig. 47: 36-42 (1973)

19. Im JG, Kim YS, Ha TY. Effect of sorghum flour addition on the quality characteristics of muffin. Korean J. Food Sci. Technol. 30: 1158-1162 (1998)

20. Oh SC, Nam HY, Cho JS. Quality properties and sensory characteristics of sponge cakes as affected by additions of Dioscorea japonica flour. Korean J. Soc. Food Cookery Sci. 18: 185-192 (2002)

21. Lee JH, Heo SA. Physicochemical and sensory properties of sponge cakes incorporated with Ecklonia cava powder. Food Eng. Prog. 14: 222-228 (2010)

22. Yi SY, Kim CS, Song YS, Park JH. Studies on the quality characteristics of sponge cakes with addition of yam powders. J. Korean Soc. Food Sci. Nutr. 30: 48-55 (2001)

23. Kang BS, Moon SW. Effect of rosemary powder on the physicochemical characteristics of sponge cake during storage. Korean J. Food Preserv. 16: 155-159 (2009)

24. Park JS, Lee YJ, Chun SS. Quality characteristics of sponge cake added with banana powder. J. Korean Soc. Food Sci. Nutr. 39: $1509-1515$ (2010)

25. Yoon SB, Hwang SY, Chun DS, Kong SK, Kang KO. An investigation of the characteristics of sponge cake with ginseng powder. Korean J. Food Nutr. 20: 20-26 (2007)

26. Lee JH, Kwak EJ, Kim JS, Lee YS. Quality characteristics of sponge cake added with mesangi powder. Korean J. Food Cook- ery Sci. 23: 83-89 (2007)

27. Lee JH, Son SM. Effect of Cudrania tricuspidata leaf powder addition on the quality of sponge cakes. Food Eng. Prog. 15: 376-381 (2011)

28. Park YS, Chang HG. Quality characteristics of sponge cakes containing various levels of black rice flour. Korean J. Food Sci. Technol. 39: 406-411 (2007)

29. Pomeranz Y, Shogrem MD, Finney KF, Bechter DB. Fiber in bread making effects on functional properties. Cereal Chem. 54: 25-41 (1997)

30. Chang HG. Quality characteristics of sponge cakes containing various levels of millet flour. Korean J. Food Sci. Technol. 36: 952-958 (2004)

31. Park YR, Han IJ, Kim MY, Choi SH, Shin DW, Chun SS. Quality characteristics of sponge cake prepared with red ginseng marc powder. Korean J. Food Cookery Sci. 24: 236-242 (2008)

32. Gómez M, Oliete B, Rosell CM, Pando V, Fernández E. Studies on cake quality made of wheat-chicken flour blends. LWT-Food Sci. Technol. 41: 1701-1709 (2008)

33. Choi GY, Bae JH, Han GJ. The quality characteristics of sponge cake containing a functional and natural product (1. mulberry leaf powder). J. East Asian Soc. Dietary Life 17: 703-709 (2007)

34. Choi GY, Kim HD, Bae JH. Quality characteristics of sponge cakes occurred with percentages of persimmon leaves powder added. Korean J. Culin. Res. 13: 268-278 (2007)

35. Jeong $\mathrm{CH}$, Shim KH. Quality characteristics of sponge cakes with addition of Pleurotus eryngii mushroom powders. J. Korean Soc. Food Sci. Nutr. 33: 716-722 (2004)

36. Kweon BM, Jeon SW, Kim DS. Quality characteristics of sponge cake with addition of laver powder. J. Korean Soc. Food Sci. Nutr. 32: 1278-1284 (2003)

37. Jeong CH, Kim JH, Cho JR, Ahn CG, Shim KH. Quality characteristics of sponge cake upon addition of paprika powder. Korean J. Food Preserv. 14: 281-287 (2007)

38. Cho KR. Quality characteristics of sponge cake added with leek powder. Korean J. Food Nutr. 23: 478-484 (2010)

39. Chabot JF. Preparation of food science sample for SEM. Scan. Electron Micros. 3: 279-286 (1979)

40. Lee JH, Lee SR. Analysis of phenolic substance content in Korean plant foods. Korean J. Food Sci. Technol. 26: 118-121 (1994)

41. Kim SM, Cho YS, Sung SK, Lee IG, Lee SH, Kim DG. Antioxidative and nitrite scavenging activity of pine needle and green tea extracts. Korean J. Food Sci. An. 22: 13-19 (2002)

42. Choi JM, Kim KY, Lee SH, Ahn JB. Functional properties of water extracts from different parts of Acanthopanax sessiliflorus. Food Eng. Prog. 15: 130-135 (2011) 